\title{
Adult Ageing and Social Policy: New Risks to Identity
}

\author{
Simon Biggs* and Helen Kimberley** \\ * School of Social and Political Sciences, University of Melbourne \\ E-mail: biggss@unimelb.edu.au \\ **Research and Policy Centre, Brotherhood of St Laurence \\ E-mail: hkimberley@bsl.org.au
}

This article considers changing perceptions of adult ageing and their interpretation in social policy. Once wider international trends are outlined, Australian policy is used as a case example. It is argued that a mismatch between policy initiatives and personal change is a new social risk associated with demographic and socio-cultural development, having implications for the way in which social ageism and age discrimination should be considered. The article concludes with a consideration of new directions that a critical, life course sensitised approach to social policy might take.

Keywords: Population ageing, workforce policy, ageism, life course, risk.

\section{Introduction}

When considering contemporary adult ageing, new social risks (Taylor-Gooby and Zinn, 2005; Bonoli, 2005), it will be argued, are more often than not located in the movement between policies that are changing rapidly and a set of identities and expectations which may or may not be evolving in the same direction. A possible lack of fit between these two narrative sources can result in a struggle for legitimacy, which risks the submersion of personal age-related priorities under the rubric of economic necessity. As Taylor-Gooby (2009) has pointed out, social policy has an important role in reframing the risks and parameters for social legitimacy associated with citizenship. Here, an argument is developed that contemporary trends, both nationally and internationally, have tried to solve 'the problem of demographic ageing' by legitimising identity in later life through a narrowed perspective, relying on work and work-related activity. This focus on productivity may fit some, but not all, older adults, and works toward an undifferentiated perspective on later life which obscures diversity in the experience of growing older, both across different parts of the life course labelled as old, and within groups, including differences based on gender, ethnicity and indigenous status. Such a trend is arguably driven by an intolerance of uncertainty within policy discourse preoccupied with economic concerns, which also affect a social actor's room to experiment and manoeuvre at a personal level. If, as the World Economic Forum (Beard et al., 2012) claims, the task of addressing global ageing is principally one of cultural adaptation, the forms that adaptation takes require critical consideration, including a rethinking of social ageism. Social Ageism is used here to denote the dominance of one age group's priorities over another's, often experienced as a form of 'othering' (Biggs et al., 2006, Phillips et al., 2010) and is returned to in the latter stages of this article. Rather than evidencing a cultural lag 
between old and new forms of ageing (Riley et al., 1994), it is argued that current policies attempt an erasure of any transition, thus replacing age-specific with generic life priorities.

\section{Adult ageing in changing times}

When considering the relationship between risk, identity and adult ageing, one of the first things to strike the reviewer is that a number of areas are simultaneously in flux. First, policy toward later life has changed dramatically in a relatively short period. This is true for Australia (Australian Government, 2010; Australian Treasury, 2011) as well as within wider international contexts (Walker, 2009; Moulaert and Biggs, 2012). Second, the adult life course has been subject to a number influences associated with postmodernity (Featherstone and Hepworth, 1989; Gilleard and Higgs, 2010) that have made life stages that were previously assumed to be fixed and predictable more flexible and uncertain. This trend has been associated with the growth of consumerism amongst older adults (Metz and Underwood, 2005), and has been seen as setting up a tension between bodily changes, traditional expectations of 'growing older' and new forms of uncertainty centred around social identity (Hepworth, 2004). Third, older people in particular have been claimed to be generally richer and fitter than preceding generations, posited as a combination of debilitating diseases having been pushed to the last years of life (Fries, 1980), that decrements associated with old age are increasingly modifiable and sometimes reversible (Rowe and Kahn, 1987) and by the growth of occupational pension schemes (Phillipson, 2002). Finally, changing demographic circumstances have brought relations between generations into sharper focus (Antonucci et al., 2007) which have revived discussion of generational relations, justice and empathy between groups and generations (Kohli, 2005; Moody, 2008; Biggs et al., 2011). Taken together, this new flexibility promises a new ageing in which old threats have receded and new identities can be created.

The principal social risks associated with adult ageing had traditionally been associated with changing conceptions of the relationship between infirmity, poverty and work, with retirement ages being used as both a means of marking bodily change and as a way of regulating the workforce. Perhaps the best example of the former arises from reforms in the UK at the start of the twentieth century, often resulting from trade union pressure, to recognise the toll taken by working life and the right to continued support in old age (Macnicol and Blaikie, 1989; Midwinter, 1994). By the 1980s, however, early retirement was being used to encourage older adults to leave work and make room for new, younger, cohorts of workers (Phillipson, 1986). Older adults, as workers, became a surplus labour pool, whose boundaries were to be re-drawn depending upon macroeconomic need. The early twenty-first-century international and national policy initiatives have occasioned another re-drawing of the boundaries. This time concern has specifically rested on the role of work as a legitimising force for forms of social engagement for all parts of the adult life course, including older age. Whereas threats in the preceding period were often conceived as arising from the exclusion of older adults from work, the current period has arguably reversed this trend so that older adults have been given no option other than work or work-like activity to legitimise identity (Biggs, 2004; Moulaert and Biggs, 2012). Whilst the changing boundary between work and non-work has become a key marker for economic risk, with consequences that are very real for the persons involved, it is argued here that they are accompanied by a profound, yet largely unexamined questioning of legitimacy of age-related identities which requires a re-consideration of the forms that 
social ageism might take. Without taking this second element into account, important tensions between the experience of ageing and macro-economic drivers of policy are in danger of being ignored.

\section{Rethinking policy toward adult ageing}

Under circumstances in which the meaning of adult ageing has been perceived to be in flux, particular policy priorities may constitute attempts to re-fix them, giving rise to novel configurations of risk. New forms of ageing, in other words, require new forms of policy in order to help shape their development.

The perception, both internationally as well as nationally, that the adult life course was changing, led to a number of attempts to understand, and then progressively shape what that change should be, including initiatives by the Organisation for Economic Cooperation and Development (OECD), the World Bank and the International Monetary Fund (see Estes and Phillipson, 2002). In 1998, for example, the OECD stated that new models of ageing were needed, which depended on:

The capacity of people to make flexible choices in the way they spend time over life - in learning, in work, in leisure and in care-giving. Active ageing reforms are those that remove undesirable constraints on life course flexibility and that strengthen support to citizens. (OECD, 1998: 125)

This notion of active ageing was taken up, particularly by the World Health Organisation (WHO), which in 2002 published Active Ageing: A Policy Framework. This document identified health, social participation and security as key factors, and supported the holistic vision of human development contained in the original OECD report.

These early documents appear to have focussed on the potential for personal development as a result of a long life, relatively free of bodily incapacities and with adequate personal wealth to undertake a variety of social roles. However, the recognition of new forms of ageing also gave rise to concern as how to pay for this longer, more active life, seen through the lens of the impending retirement of a relatively large cohort of pensionable 'baby boomers' (Phillipson et al., 2008). If the negative cycle, of more people retiring, making greater claims on state pensions, while not producing new wealth through work, could be changed to one with more older, fitter workers, paying taxes and not drawing benefits, then adult ageing, perceived as a fiscal problem, could be turned into a fiscal advantage.

By 2006, the OECD had continued its mission of promoting pension and active ageing reforms by a thematic analysis of twenty-one countries and produced its conclusions in Ageing and Employment Policies: Live Longer, Work Longer (OECD, 2006). This report, as the title suggests, appeared to have solved the problem of population ageing. The final version did not refer to 'active ageing', focussing entirely on employment as the solution to what to do with an ageing population. It is from this discourse that national governments, including Australia, appear to have taken their cue.

\section{Changes to Australian policy}

Australia has engaged in a number of initiatives that concern population ageing. In 2002, the then Liberal Government produced a National Strategy for an Ageing 
Australia (Australian Government, 2002a), which engaged in stakeholder consultation, and more recently the Labour Government has undertaken a number of policy reviews and consultations, which will be summarised below. Australia is perhaps unique in that since the beginning of the twenty-first century, policy debate has included the regular production of 'Intergenerational Reports' (Australian Government: 2002b, 2007, 2010). Policy on ageing has centred around these reports that are produced for the Commonwealth Government by a quasi-independent Productivity Commission which exists under the auspices of the Australian Treasury. So far, reports have been produced in 2002, 2007 and 2010. These reports have become closely associated with anxiety about the ability of future generations to support a growing older population (Kendig, 2010). To date all three intergenerational reports comprise analyses of long term trends, such as migration and climate change, on economic competitiveness, and in this context examine the impact of an ageing population on Australia's economic future. Each of the three reports postulates ageing as an economic burden to society. The third and most recent report states that:

In addition to assessing the fiscal and economic challenges of an ageing population, this report also includes a comprehensive discussion on environmental challenges and social sustainability. The report assesses the challenges Australia will face over the next 40 years, including an ageing population, escalating pressures on the health system, and the environmental and economic challenges of climate change. (Australian Government, 2010: 1)

In addition to linking population ageing to long-term threats, such as climate change, debate on ageing has also been closely associated with migration policy and other attempts to engineer a particular form of social future. This narrative is associated with undercurrents of risk to national and cultural security and whether the projected 'younging' of Australia through migration is a fact (Norman and Meikle, 1983), or an illusion (Withers, 1999). It reflects a wider ambivalence in Australian policy toward the role of future migration in a nation largely made up of migrants and a long history of attempts to control the perceived threat that uncontrolled and unfiltered migration might pose (MacDonald and Kippen, 2000). It is perhaps instructive that unlike the EU's guidance on subsidiarity and UK regulations that sit within it, Australian restrictions on migration include age as a criterion for exclusion, starting at forty-five years (Australian Government, 2012a). Social sustainability, in the context of population ageing, relies on reducing pension and health expenditure and manipulating immigration criteria to keep Australia 'a young country' in the national imagination. While population ageing is sometimes presented as a policy success, its implications are therefore imbued with a national anxiety, not just of cost, but of identity.

Debate on the Intergenerational Reports has almost exclusively centred around whether the numbers add up, with little consideration of underlying assumptive realities. The current head of the Productivity Commission has acknowledged the difficulties of forward prediction (Banks, 2011) and states that the proportion of older adults will be less than figures forecast in 2003 by some 8 million. Spies Butcher and Stebbing (2011) argue that it is the Treasury's systemic conservative bias that manufactures a crisis where one may not actually exist, while the Australian expert on labour economy, Bob Gregory, is quoted as believing that large-scale change in population age profiles is not a serious problem (The Australian, 2010). Kudrna and Woodland (2011) conclude, in a Productivity 
Commission review, that: 'the literature does not provide clear answers as to how an ageing population will affect, for example, living standards, capital labour ratio and real wages' (2011: 64). The predictive validity of the Report is not helped by its conflation of the projected cost of aged care with the entire health budget, with the implication that it is the ageing population alone that will be responsible for any increase. Debate has ventured briefly into questions of age and risk, and the 2010 Intergenerational Report has been criticised for ignoring the needs of younger adults (Bessant et al., 2011). Bessant et al. have suggested a 'generational accounting' model to restore a youth-based form of social justice, whereby each generational group pays for itself across the life course. Putting aside the difficulty of defining a generation for fiscal purposes and the point at which one becomes 'elderly', these models seek to solve the problem of risk posed in, as opposed to by, old age, simply by excluding it. As Smyth (2010) has pointed out, historically the Australian solution to social exclusion has been one of finding work and of self sufficiency; indeed Australia had been referred to as 'wage-earner's welfare state'. In other words, inclusion was ensured, theoretically at least, through a right to work and benefits largely made available though additions or tax exclusions around wage-earning. One is therefore left with a curious situation in which there is little criticism or even debate around the underlying assumptions concerning ageing, work and identity. Indeed, in this context, the rethinking of age as a time of work is seen as simply common sense. This focus has been complemented by the appointment of a Commissioner for Age Discrimination. If the stick for older workers is an increase in pension age, the carrot is a renewed attempt to reduce workplace discrimination based on age.

A spilt between active, working older Australians, and those whose frailty requires residential and health care, is exemplified by two reports, both released in 2011. The first, was produced by the Productivity Commission, called Caring for Older Australians, and attempts to find a means of reducing the cost of residential care. It received wide support from large care-home providers in its attempt to reduce the fiscal costs of population ageing by emphasising support in the community, increasing the supply of residential care and facilitating the re-mortgaging of older people's own property to release capital to pay for care (Productivity Commission, 2011). The report has been urged on Government by the Business Council of Australia as a 'user-pays' solution to population ageing (Business Council of Australia, 2012). The year 2011 also saw the publication of three Treasury reports under the general rubric of the Economic Potential of Senior Australians (EPSA) (Australian Government, 2011a, 2011b, 2011c), which constitute an attempt to re-position older adults within the policy debate. The narrative is upbeat and asserts the potential contribution that older adults might play rather than the burden that they present. In the section entitled 'Capturing and realising this economic potential', the questions are posed: 'Will Australian society adapt and capture the opportunities that an ageing population creates? Or will it watch this opportunity slip by? Will Australia capitalise on the potential of this source of skilled workers and experienced carers? Will it invest in new markets for goods and services for an expanded number of older people?' (2011a: 3). As such, economic potential has been interpreted broadly to include non-work-based community and family contributions as well as a potential new market for Australian business. Both of these reports have resulted in a federal response entitled Living Longer, Living Better (Australian Government, 2012b), which takes on board the majority of the recommendations made. 
There are at least three things that are striking about Australian policies on population ageing. First, risk has almost exclusively been conceived as threats posed by older adults to others, most commonly posed as an economic one and as a threat to the well-being of future generations. Further, rather than being a source of personal risk, the question has been elevated to one of national and international proportions.

Second, that policy has responded to uncertainty, or flux, in ageing identities by adopting a narrowed definition of social legitimacy, most notably through work or worklike activities. At the level of policy, this reduces risk, in so far as a new normative identity has been produced; however, at a personal level, the ageing adult is placed at further risk, in so far as other forms of personal development are not valued and may conceivably be seen as deviant or illegitimate.

Third, the cultural adaptation required of societies experiencing population ageing has been defined principally as one of finding ways to increase forms of workforce participation or through unpaid work, such as volunteering. New identities de-emphasise risks associated with bodily decline or financial insecurity and valorise continuity of social contribution. Other forms of personal development are not seriously addressed. A consensus appears to have arisen with little consideration of whether this is the only or even the most appropriate cultural adaptation to be made. The default model for social legitimation has, by extension, become one of continuity with previous phases of the adult life course, most notably through continued working life, howsoever the opportunities and risks associated with this limited form of inclusion arise.

\section{Rethinking the rethinking: discontinuity, the adult life course and social ageism}

Both international and Australian policy change, then, centre on work and work-related activities as the principal solution to population ageing. A supposed liberation from old dependencies has, as Beck (1992) forewarned, made individual identity increasingly dependent on the labour market. As Patrick (2012) has pointed out, responsibility to work has become the hallmark of legitimate citizenship across a wide number of policy domains. What is perhaps surprising is the absence of a critical response to this new relationship in the area of adult ageing and continuing work. Historically, social gerontologists active in policy formation, while differing on the capacity of work under capitalism to offer fulfilment in later life (Phillipson, 1986; Walker and Naegele, 1999; Estes and Associates, 2001; Guillemard and Jolivet, 2006), have generally not questioned an exclusion from work as one of the core mechanisms disempowering older adults. An assumption that work is somehow the solution to the problem of powerlessness in later life, arises from influences within critical political economy, that power in society is based on work, because work is the principal way that ordinary people have for interacting with the processes of production. To be engaged in work is to gain some influence and social value, however marginal. The social construction of old age, as argued since Townsend (1986), excluded older people through compulsory retirement which then condemned them to poverty and institutionalisation. According to this logic, continuing to work is, by contrast, anti-ageist, a conclusion that has now found favour within mainstream policy on ageing. Putting aside the poor quality of work often available to older adults (Bowman and Kimberley, 2012) and the effects of cumulative disadvantage that can flow from it (Dannefer, 2003), the fact that work has now emerged as a legitimising discourse of almost 
hegemonic proportions significantly weakens the critical force of this argument, and it may be necessary to look for alternative sources of critique.

A revitalised critical approach may lie, not only in a re-discovery of the negative effects of work, but also by drawing attention to changes in priority that arise with ageing, so that continuity, and particularly continuity of identity through work, comes to be seen as a break on personal development rather than its source. The current policy settlement assumes that identity risk lies in threats to that continuity, whereas a more nuanced psycho-social approach would indicate that discontinuity plays as important a role in developing an age-specific identity and that risk may effectively lie in enforced roles that deny access to such personal change.

Evidence that the adult life course consists of a number of psycho-social discontinuities can be found in a diverse set of discourses, including psychotherapy, social psychology and anthropology, as well as in social gerontology itself. Examples of changes, important to identity and evolving life priorities, exist in an increased awareness of death (Jaques, 1965), a need to integrate different narrative strands into a distinctive life story (McAdams, 1997, 2011), cultural diversity with respect to changing gender roles (Guttman, 1987; Sheehey, 1996; Arber, 2006; Calasanti and King, 2011), differences in priority between the first and second halves of adult life (Dittmann-Kohli and Joop, 2007) and an accommodation to the demands of both youthful and mature identities (Biggs et al., 2008). Summarising responses to the SELE (Self and Life) sentence completion instrument from the German Ageing Study, for example, Dittman-Kohli and Joop (2007) found distinctive differences between the responses of younger, midlife and older adults. A shift with age took place as concerns with social achievement became less central, and existential ones (time, health, death, impermanence, contingency, finitude) more so. Such findings tend to support Tornstam's (2005) contention, attributing enhanced coping in later life, in his Swedish and Danish sample, to a process called gerotranscendence: 'the gerotranscendent individual ... typically experiences a re-definition of the self and of relationships to others and a new understanding of fundamental, existential questions. The individual, becomes, for example, less self-preoccupied and the same time more selective in the choice of social and other activities' (2005: 3). He argues that an adaptive ageing identity is marked by an enhanced awareness of the difference between self and role, in the sense of distinguishing between the development of what is unique about the self rather than conforming to an appropriate social niche and preoccupation with one's job, appearance and ego.

Taken together, these findings suggest that responding to personal existential risks to identity in later life generates a qualitative change in attitudes which are distinctive and adaptive to the point individuals have reached in their own life course. They therefore question any position which imposes continuity of role and value, as is the case within contemporary social policy that exclusively connects legitimate age identity with work. To do so would be to deny positive discontinuities, ones that can arise from changing life priorities brought on, in part, by the experience of growing older itself. Whereas in previous periods, risk to identity lay in exclusion from work, it may now lie in a denial of any alternative.

One result of this analysis is that age discrimination may not now be primarily a problem of access, but of age-colonisation. Debates over social ageism, in which age discrimination has played an important role, have tended to concentrate on content issues, such as the compulsory exclusion of older adults from the workforce (Bytheway, 2005). 
However, as this work-choice has become both more coercive, and the dominant source of social legitimation in later life, a new way of critical examination via social ageism may be necessary, that relies less on the specific site of discrimination and more on the relationship between continuity and discontinuity in life course processes. A process approach to ageism may need to include the imposition of the goals, aims, priorities and agendas of one age group onto and into the lives of other age groups. This may be consciously done, for reasons of political or economic expediency, or done unknowingly as if these priorities are simply commonsense' (Biggs, 2004: 103). The problem of ageism may not so much now be a problem of 'othering', as suggested by Butler (1975) and Phillips et al. (2010), but of over inclusiveness. In other words, we do not create an ageist society by making some older people 'not us' and 'different', but by trying to make them too much like ourselves. Positive forms of othering, the recognition of diversity within age groups and across different phases of the life course, may actually enhance individual and group development via the discovery of new forms of contribution, based on the specific capabilities that each age brings.

\section{Working toward a new policy agenda}

The implications for social policy are considerable. First, increased working life may not be the most adaptive cultural shift provoked by population ageing if it inhibits the discovery of novel age-related roles and contributions. Second, age discrimination may not exist in allowing access to forms of activity that are not age adaptive, but in failing to adapt to the changing priorities of a long life. This would mean that where older workers wished to work, workplaces should be modified to encourage them, rather than relying on coercive economic practices that make it hard to live affordably and not work. Work would be seen as a solution for some, but by no means all, mature adults; rather, spaces should be created where alternative forms of contribution can be explored. Third, once age-specific contributions have been given space for expression, they would have the added value of not expecting different generational groups to compete for the same roles and identities. Fourth, complementary roles should be explored that reduce rather than increase the possibility of intergenerational conflict. Fifth, the contribution of older adults might be assessed longitudinally rather than simply on one's capacity to be productive in the here and now, a process that might inform new ways of achieving work-life balance and the wider valorisation of non work-like activities. Finally, while population ageing often appears as an afterthought in policy, a refuge for uncritical and unexplored assumptions about later life, it has the capacity to draw attention to issues of complementary contribution and the balance between work and life across the life course. It throws a critical light on policy assumptions that affect all age groups.

The question becomes both: Is there more to life than work? And is work the most adaptive cultural shift in response to a long life? It is not now simply the exclusion from work that is at issue, but the balance between work and changing life priorities expressed longitudinally. The recognition of discontinuity of priorities as a positive force for personal development allows the reintroduction of non-work and even anti-work based agency into the debate on the purpose of a long life. Adhering to a model that allows the imposition of agendas devised from one part of the life course into another; for example child labour, or compulsory work in old age balanced by the threat of poverty, can be expected to contribute to novel forms of identity risk, rather than novel forms of adaptation. The 
problem with living in historically unprecedented times, as is the case for population ageing, is that there are few pre-existing models to draw on. The role of policy would be to reserve judgement enough to allow novel adaptive realities to evolve, rather than to suppress them.

\section{References}

Antonucci, T. C., Jackson, J. S. and Biggs, S. (2007) 'Intergenerational relations: theory, research and policy', Journal of Social Issues, 63, 4, 679-94.

Arber, S. (2006) 'Gender and later life: change, choice and constraints', in J. Vincent, C. Phillipson and M. Downs (eds.), The Futures of Old Age, London: Sage.

Australian Government (2002a) National Strategy for an Aging Australia, Canberra: Commonwealth of Australia.

Australian Government (2002b) Intergenerational Report 2002, Canberra: Commonwealth of Australia, http://archive.treasury.gov.au/igr/igr2010/default.asp [accessed 07.02.2012].

Australian Government (2007) Intergenerational Report 2007, Canberra: Commonwealth of Australia, http://archive.treasury.gov.au/igr/igr2010/default.asp [accessed 04.02.2012].

Australian Government (2010) Australia to 2050: Future Challenges, Intergenerational Report 2010, Canberra: Commonwealth of Australia, http://archive.treasury.gov.au/igr/igr2010/default.asp [accessed 04.02.2012].

Australian Government (2011a) Realising the Economic Potential of Senior Australians: Changing Face of Society, first report of the Advisory Panel on the Economic Potential of Senior Australians, Canberra: Commonwealth of Australia.

Australian Government (2011b) Realising the Economic Potential of Senior Australians: Enabling Opportunity, second report of the Advisory Panel on the Economic Potential of Senior Australians, Canberra: Commonwealth of Australia.

Australian Government (2011c) Realising the Economic Potential of Senior Australians: Turning Grey into Gold, third report of the Advisory Panel on the Economic Potential of Senior Australians, Canberra: Commonwealth of Australia.

Australian Government (2012a) Immigration Criteria, Canberra: Commonwealth of Australia, http://www. immi.gov.au/ [accessed 05.02.2012].

Australian Government (2012b) Living Longer, Living Better, Canberra: Commonwealth of Australia.

Australian Treasury (2011) Realising the Economic Potential of Senior Australians, Canberra: Commonwealth of Australia.

Banks, G. (2011) 'Introduction', in Productivity Commission, A Sustainable Population? Key Policy Issues, Canberra: Commonwealth of Australia, pp. 1-8.

Beard, J. R., Biggs, S., Bloom, D. E., Fried, L., Hogan, P., Kalache, A. and Olshansky, S. J. (2012) Global Population Ageing: Peril or Promise?, Geneva: World Economic Forum.

Beck, U. (1992) Risk Society, London: Sage.

Bessant, J. C., Emslie, M. and Watts, R. (2011) 'Accounting for future generations: intergenerational equity in Australia', Australian Journal of Public Administration, 70, 2, 143-55.

Biggs, S. (2004) 'New ageism: age imperialism, personal experience and ageing policy', in S.-O. Daatland and S. Biggs (eds.), Ageing and Diversity, Bristol: Policy, pp. 95-106.

Biggs, S., Phillipson, C., Money, A. M. and Leach, R. (2006) 'The age-shift: observations on social policy, ageism and the dynamics of the adult lifecourse', Journal of Social Work Practice, 20, 3, 239-51.

Biggs, S., Leach, R., Phillipson, C., Ogg, J. and Money, A. M. (2008) 'The mature imagination and consumption strategies: age and generation in the development of a UK baby boomer identity', International Journal of Ageing and Later Life, 2, 2, 31-59.

Biggs, S., Haapala, I. and Lowenstein, A. (2011) 'Exploring generational intelligence as a model for examining the process of intergenerational relationships', Ageing and Society, 31, 3, 353-71. 
Bonoli, Giuliano (2005) 'The politics of new social policies: providing coverage against new social risks in mature welfare states', Policy and Politics, 33, 3, 431-49.

Bowman, D. and Kimberley, H. (2012) Sidelined: Workforce Participation and Non Participation among Older Australians, Melbourne: Brotherhood of St Laurence.

Bytheway, B. (2005) Ageism, Buckingham: Oxford University Press.

Business Council of Australia (2012) 'More work needed to achieve quality sustainable aged care', http://www.bca.com.au/Content/101971.aspx [accessed 04.02.2012].

Butler, R. (1975) Why Survive? Being old in America, New York: Harper \& Row.

Calasanti, T. and King, N. (2011) 'A feminist lens on the third age: refining the framework', in D. Carr and K. Komp (eds.), Gerontology in the Era of the Third Age, New York: Springer.

Dannefer, D. (2003) 'Cumulative advantage/disadvantage and the life course: cross-fertilizing age and social science theory', Journal of Gerontology, B, 58, 6, S327-37.

Dittman-Kohli, F. and Joop, D. (2007) 'Self and life-management', in J. Bond (ed.), Ageing in Society, London: Sage, pp. 268-95.

Estes, C. and Associates (2001) Social Policy and Aging: A Critical Perspective, Thousand Oaks, CA: Sage Publications.

Estes, C. and Phillipson, C. (2002) 'The globalisation of capital, the welfare state and old age policy', International Journal of Health Services, 32, 2, 279-97.

Featherstone, M. and Hepworth, M. (1989) 'Ageing and old age: reflections on the post-modern life course', in B. Bytheway (ed.), Becoming and Being Old: Sociological Approaches to Later Life, London: Sage, pp. 143-57.

Fries, J. F. (1980) 'Aging, natural death, and the compression of morbidity', New England Journal of Medicine, 303, 3, 130-5.

Gilleard, C. and Higgs, P. (2010) 'Generational conflict, comsumption and the ageing welfare state in the United Kingdom', Ageing and Society, 30, 8, 1439-51.

Guillemard, A.-M. and Jolivet, A. (2006) De l'emploi des seniors à la gestion des âges, Paris: La Documentation française.

Guttman, D. (1987) Reclaimed Powers, London: Hutchinson.

Hepworth, M. (2004) 'Embodied agency, decline and the mask of ageing', in E. Tulle (ed.), Old Age and Agency, New York: Nova.

Jaques, E. (1965) 'Death and the midlife crisis', International Journal of Psychoanalysis, 46, 4, 50714.

Kendig, H. (2010) 'The Intergenerational Report 2010: a double-edged sword', Australasian Journal on Ageing, 29, 4, 145-6.

Kohli, M. (2005) 'Generational changes and generational equity', in M. L. Johnson (ed.), The Cambridge Handbook of Age and Ageing, Cambridge: Cambridge University Press, pp. 518-26.

Kudrna, M. and Woodland, M. (2011) 'Economic effects of population growth and ageing in Australia', in Productivity Commission, A Sustainable Population? Key Policy Issues, Canberra: Commonwealth of Australia, pp. 41-56.

MacDonald, P. and Kippen, R. (2000) The Impact of Immigration on the Ageing of Australia's Population, www.immi.gov.au/media/statistics/population/ageing.pdf [accessed 20.07.2012].

Macnicol, J. and Blaikie, A. (1989) 'The politics of retirement', in M. Jeffreys (ed.), Growing Old in the Twentieth Century, London: Routledge, pp. 21-43.

McAdams, D. P. (1997) The Stories We Live By, New York: Morrow.

McAdams, D. P. (2011) 'Life narratives', in K. L. Fingerman, C. A. Berg, J. Smith and T. C. Antonucci (eds.), Handbook of Lifespan Development, New York: Springer, pp. 589-610.

Metz, D. and Underwood, M. (2005) Older Richer Fitter, London: Age Concern England.

Midwinter, E. (1994) The Development of Social Welfare in Britain, Buckingham: Open University Press.

Moody, H. R. (2008) 'Aging America and the boomer wars', The Gerontologist, 48, 6, 839-44.

Moulaert, T. and Biggs, S. (2012) 'International and European policy on work and retirement: reinventing critical perspectives on active ageing and mature subjectivity', Human Relations, 65, 9, 23-35. 
Norman, N. and Meikle, K. (1983) Immigration - The Crunch Issues for Australia, Information Paper IP8 CEDA Research Department, Melbourne: CEDA.

OECD (1998) Maintaining Prosperity in an Ageing Society, Paris: OECD.

OECD (2006) Ageing and Employment Policies: Live Longer, Work Longer, Paris: OECD.

Patrick, R. (2012) 'Work as the primary "duty" of the responsible citizen: a critique of this work-centric approach', People, Place and Policy Online, 6, 1, 5-15.

Phillips, J., Ajrouch, K. and Hillcoat, S. (2010) Key Concepts in Gerontology, London: Sage.

Phillipson, C. (1986) Capitalism and the Construction of Old Age, London: Macmillan.

Phillipson, C. (2002) Transitions from Work to Retirement: Developing a New Social Contract, Bristol: The Policy Press.

Phillipson, C., Leach, R., Money, A.-M. and Biggs, S. (2008) 'Social and cultural constructions of ageing: the case of the baby boomers', Sociological Research Online, 13, 3, 5, http://www.socresonline.org. uk/13/3/5.html [accessed 02.07.2012].

Productivity Commission (2011) Caring for Older Australians, Canberra: Productivity Commission.

Riley, M. W., Khan, R. L. and Foner, A. (1994) Age and Structural Lag, New York: Wiley.

Rowe, J. W. and Kahn, R. I. (1987) 'Human Aging: usual and successful', Science, 237, 4811, 143-49.

Sheehey, G. (1996) New Passages: Mapping Your Life across Time, New York: Harper-Collins.

Smyth, P. (2010) In or Out? Building an Inclusive Nation, Melbourne: Brotherhood of St Laurence.

Spies Butcher, B. and Stebbing, A. (2011) 'Population ageing and tax reform in a dual welfare state', The Economics and Labour Relations Review, 22, 3, 45-64.

Taylor-Gooby, P. and Zinn, J. (2005) Current Directions in Risk Research: Reinvigorating the Social, Working Paper 5, Canterbury: University of Kent.

Taylor-Gooby, P. (2009) Reframing Social Citizenship, Oxford: Oxford University Press.

The Australian (2010) 'Commentary on the intergenerational report', 2 March.

Tornstam, L. (2005) Gerotranscendence, New York: Springer.

Townsend, P. (1986) 'Ageism and social policy', in C. Phillipson and A. Walker (eds.), Ageing and Social Policy, Aldershot: Gower, pp. 15-44.

Walker, A. (2009) 'Commentary: the emergence and application of active aging in Europe', Journal of Aging and Social Policy, 21, 1, 75-93.

Walker, A. and Naegele, G. (1999) The Politics of Old Age in Europe, Buckingham: Open University Press.

Withers, G. (1999) A Younger Australia?, Discussion Paper No. 63, Public Policy Program, Canberra: Australian National University.

World Health Organisation (WHO) (2002) Active Ageing: A Policy Framework, Geneva: WHO. 